Inventories and scenarios of nitrous oxide emissions

This content has been downloaded from IOPscience. Please scroll down to see the full text. 2014 Environ. Res. Lett. 9105012

(http://iopscience.iop.org/1748-9326/9/10/105012)

View the table of contents for this issue, or go to the journal homepage for more

Download details:

IP Address: 128.59.161.126

This content was downloaded on 26/02/2015 at $16: 24$

Please note that terms and conditions apply. 


\title{
Inventories and scenarios of nitrous oxide emissions
}

\author{
Eric A Davidson ${ }^{1}$ and David Kanter ${ }^{2}$ \\ ${ }^{1}$ The Woods Hole Research Center, 149 Woods Hole Road, Falmouth, MA 02540-1644, USA \\ ${ }^{2}$ The Earth Institute, Columbia University, 535 West 116th Street, New York, NY 10027, USA \\ E-mail: davidsoneric@comcast.net
}

Received 31 May 2014, revised 6 August 2014

Accepted for publication 19 September 2014

Published 27 October 2014

\begin{abstract}
Effective mitigation for $\mathrm{N}_{2} \mathrm{O}$ emissions, now the third most important anthropogenic greenhouse gas and the largest remaining anthropogenic source of stratospheric ozone depleting substances, requires understanding of the sources and how they may increase this century. Here we update estimates and their uncertainties for current anthropogenic and natural $\mathrm{N}_{2} \mathrm{O}$ emissions and for emissions scenarios to 2050. Although major uncertainties remain, 'bottom-up' inventories and 'top-down' atmospheric modeling yield estimates that are in broad agreement. Global natural $\mathrm{N}_{2} \mathrm{O}$ emissions are most likely between 10 and $12 \mathrm{Tg} \mathrm{N}_{2} \mathrm{O}-\mathrm{N} \mathrm{yr}^{-1}$. Net anthropogenic $\mathrm{N}_{2} \mathrm{O}$ emissions are now about $5.3 \mathrm{Tg} \mathrm{N}_{2} \mathrm{O}-\mathrm{N} \mathrm{yr}^{-1}$. Gross anthropogenic emissions by sector are $66 \%$ from agriculture, $15 \%$ from energy and transport sectors, $11 \%$ from biomass burning, and $8 \%$ from other sources. A decrease in natural emissions from tropical soils due to deforestation reduces gross anthropogenic emissions by about $14 \%$. Business-as-usual emission scenarios project almost a doubling of anthropogenic $\mathrm{N}_{2} \mathrm{O}$ emissions by 2050. In contrast, concerted mitigation scenarios project an average decline of $22 \%$ relative to 2005 , which would lead to a near stabilization of atmospheric concentration of $\mathrm{N}_{2} \mathrm{O}$ at about $350 \mathrm{ppb}$. The impact of growing demand for biofuels on future projections of $\mathrm{N}_{2} \mathrm{O}$ emissions is highly uncertain; $\mathrm{N}_{2} \mathrm{O}$ emissions from second and third generation biofuels could remain trivial or could become the most significant source to date. It will not be possible to completely eliminate anthropogenic $\mathrm{N}_{2} \mathrm{O}$ emissions from agriculture, but better matching of crop $\mathrm{N}$ needs and $\mathrm{N}$ supply offers significant opportunities for emission reductions.
\end{abstract}

Keywords: climate change, greenhouse gases, $\mathrm{N}_{2} \mathrm{O}$, nitrogen cycle, ozone depleting substance, representative concentration pathways, RCPs

\section{Introduction}

As the third most important anthropogenic greenhouse gas and the largest remaining anthropogenic stratospheric ozone depleting substance currently emitted, nitrous oxide $\left(\mathrm{N}_{2} \mathrm{O}\right)$ is one of the most important forms of nitrogen $(\mathrm{N})$ pollution (Ravishankara et al 2009, Ciais et al 2013). Excess N pollution has been identified as one of the three global environmental issues whose 'planetary boundary' has been surpassed (Rockström et al 2009). Once an $\mathrm{N}$ atom is in a reactive form, it can contribute to a number of cascading environmental problems as it is transported through terrestrial and aquatic ecosystems and into the atmosphere (Galloway et al 2003). Effective mitigation for $\mathrm{N}_{2} \mathrm{O}$ emissions requires understanding of the sources and how they may increase this century.

$\mathrm{N}_{2} \mathrm{O}$ is a by-product of several fundamental natural reactions of the $\mathrm{N}$ cycle: nitrification, denitrification, and chemo-denitrification (Firestone and Davidson 1989). Humans began altering the natural $\mathrm{N}$ cycle as they expanded agricultural land, used fire as a land clearing and management tool, and cultivated leguminous crops that carry out biological $\mathrm{N}$ fixation. Human alteration accelerated dramatically with the discovery of the Haber-Bosch process, the chemical process that synthetically transforms atmospheric dinitrogen $\left(\mathrm{N}_{2}\right)$ gas into ammonia $\left(\mathrm{NH}_{3}\right)$ (Erisman et al 2008). The 


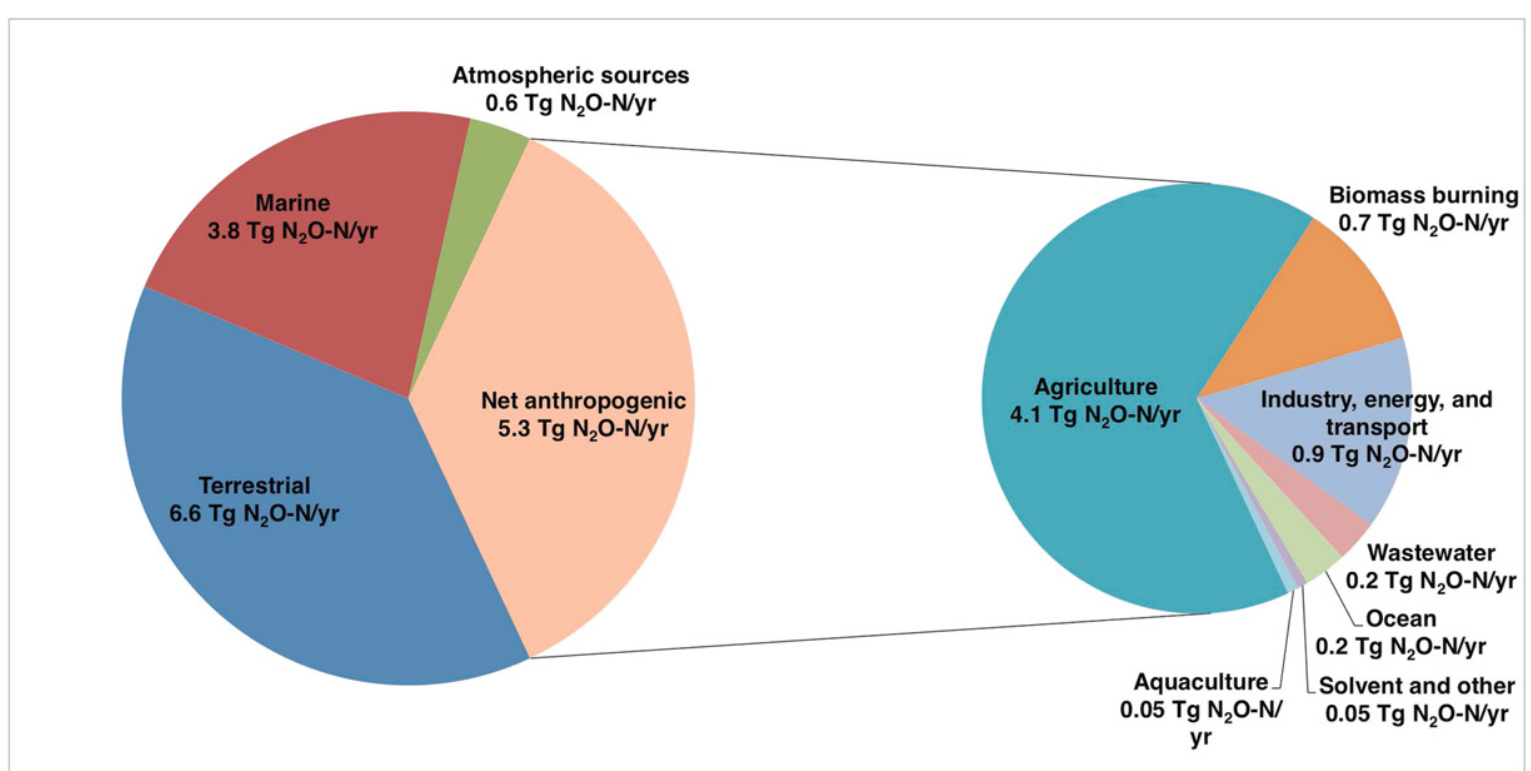

Figure 1. Natural versus anthropogenic $\mathrm{N}_{2} \mathrm{O}$ emissions in 2005. The values for natural emissions (terrestrial, marine, and atmospheric chemistry in the pie chart on the left) are taken from Ciais et al (2013), while the anthropogenic values are the best estimate values by sector from the 2013 UNEP report (Bouwman et al 2013, Oenema et al 2013, van der Werf et al 2013, Wiesen et al 2013), as summarized in table 1 of this paper. The net anthropogenic estimate in the left pie chart takes into account the effect of land use change on reducing net anthropogenic emissions (about $0.9 \mathrm{Tg} \mathrm{N}_{2} \mathrm{O}-\mathrm{N} \mathrm{yr}^{-1}$, see section 3.2). Reprinted, with permission, from Davidson et al (2013), (figure 3.1).

industrial production of $\mathrm{NH}_{3}$ led to the development synthetic $\mathrm{N}$ fertilizers, which play a central role in feeding the world's rapidly increasing population. Without the Haber-Bosch process, about half of the world's population today would likely not be adequately nourished (Erisman et al 2008). This growth in anthropogenically-fixed $\mathrm{N}$ has simultaneously led to an unintended increase in global $\mathrm{N}$ pollution, including $\mathrm{N}_{2} \mathrm{O}$ emissions, driven largely by the fact that mismatch between crop $\mathrm{N}$ demand and soil $\mathrm{N}$ supply frequently leads to $\mathrm{N}$ losses. With the possible exception of certain industrial point sources, it is impossible to completely eliminate global $\mathrm{N}$ pollution, particularly from agriculture-its largest source.

This paper first updates constraints on estimates and their uncertainties for anthropogenic and natural components of $\mathrm{N}_{2} \mathrm{O}$ emissions by biome and by anthropogenic sector. We then consider a suite of emissions scenarios for $\mathrm{N}_{2} \mathrm{O}$, including those of the recent Representative Concentration Pathways (RCPs) of the Intergovernmental Panel on Climate Change (IPCC, van Vuuren et al 2011a) and a recent special United Nations report on $\mathrm{N}_{2} \mathrm{O}$ (UNEP 2013), and the magnitude of mitigation efforts that would be needed to stabilize atmospheric $\mathrm{N}_{2} \mathrm{O}$ by 2050 . Future potential emissions from biofuels are discussed separately given particularly high levels of uncertainty for this sector. This paper integrates the authors' contributions to that UNEP report, other chapters in that report, the IPCC fifth assessment (AR5), and other recent literature for the most recent information on $\mathrm{N}_{2} \mathrm{O}$.

\section{Natural emissions}

The first approach to emission estimation is called 'bottomup,' because it sums up emission inventories from field measurements, organized according to ecosystem type or by geographic region. Using the 'bottom-up' approach, published central estimates of current natural emissions of $\mathrm{N}_{2} \mathrm{O}$ from terrestrial, marine and atmospheric sources based on several inventories range from 10 to $12 \mathrm{Tg} \mathrm{N}_{2} \mathrm{O}-\mathrm{N} \mathrm{yr}^{-1}$ (Mosier et al 1998, Galloway et al 2004, Crutzen et al 2008, Syakila and Kroeze 2011). The IPCC AR5 (Ciais et al 2013) estimated that current natural sources of $\mathrm{N}_{2} \mathrm{O}$ add up to roughly 11 (range 5.4-19.6) $\mathrm{Tg} \mathrm{N}_{2} \mathrm{O}-\mathrm{N} \mathrm{yr}^{-1}$, which is the sum of emissions from terrestrial (6.6; range 3.3-9.0), marine (3.8; range 1.8-9.4) and atmospheric sources (0.6; range: 0.3-1.2; see figure 1). Note that the indicated uncertainty ranges from each bottom-up estimate are added together to produce the large range about the AR5 global estimate. Combining estimates of natural and anthropogenic emissions from Ciais et al 2013 and the 2013 UNEP report (see section 3) respectively, we estimate that natural emissions account for approximately two thirds of total global $\mathrm{N}_{2} \mathrm{O}$ emissions (figure 1).

A second approach is called 'top-down,' because it is based on atmospheric measurements and an inversion model. Prather et al (2012) provide a spreadsheet model; here we employ the one-box mixing model of Daniel et al (2007):

$$
E=\frac{m_{i+1}-m_{i} \mathrm{e}^{-t / \tau}}{f \tau\left(1-\mathrm{e}^{-t / \tau}\right)},
$$

where $E$ is annual emissions $\left(\mathrm{Tg} \mathrm{N}_{2} \mathrm{O}-\mathrm{N} \mathrm{yr}^{-1}\right), m_{i+1}$ and $m_{i}$ are the observed atmospheric mixing ratios $\left(\mathrm{ppb}_{2} \mathrm{O}\right)$ at the start of consecutive years, $\tau$ is the lifetime, $t$ is 1 year, and f relates the mass burden to the mixing ratio $\left(0.21 \mathrm{ppb} \mathrm{N}_{2} \mathrm{O} / \mathrm{Tg} \mathrm{N}\right.$; Prather et al 2012). 
Estimates of atmospheric $\mathrm{N}_{2} \mathrm{O}$ mixing ratios (specifically, the tropospheric mean mole fraction) prior to the industrial revolution are from ice cores measurements, which were at an approximate steady state from 1730 to 1850 (Machida et al 1995). An important source of uncertainty in the topdown approach is the estimated atmospheric lifetime of $\mathrm{N}_{2} \mathrm{O}$. Most estimates range between the IPCC-AR4 assumption of 114 years (Forster et al 2007) to 131 (Prather et al 2012). The Stratosphere-troposphere Processes And their Role in Climate report (SPARC 2013) suggests 123 years as the 'recommended' estimate, with the 'most likely range' between 104 and 152 years. Because of this large range in estimates from a number of respected sources, we choose here to use only two significant figures. We round the SPARC recommended estimate to 120 years, with an uncertainty range 110-130 years, which encompasses most of the range of central estimates used commonly in the literature. We also assume that the lifetime has not changed substantially, due to a lack of compelling evidence to the contrary. With these assumptions, pre-industrial emissions are estimated to be about $11 \mathrm{Tg} \mathrm{N} \mathrm{N}_{2} \mathrm{O}-$ $\mathrm{N} \mathrm{yr}^{-1}$, with an uncertainty range of $10-12 \mathrm{Tg} \mathrm{N}_{2} \mathrm{O}-\mathrm{N} \mathrm{yr}^{-1}$. The sensitivity of the estimate is a change of about $1 \mathrm{Tg} \mathrm{N}_{2} \mathrm{O}$ $\mathrm{N} \mathrm{yr}^{-1}$ of pre-industrial emissions for every 10 years change in assumed lifetime. Hence, if the lifetime was as long as about 140 years in the pre-industrial period, the emissions estimate would be $9 \mathrm{Tg} \mathrm{N}_{2} \mathrm{O}-\mathrm{N} \mathrm{yr}^{-1}$ (Prather et al 2012). The central estimates of both top-down and bottom up approaches for pre-industrial natural emissions are in agreement at $11 \mathrm{Tg}$ $\mathrm{N}_{2} \mathrm{O}-\mathrm{N} \mathrm{yr}^{-1}$, although both have considerable uncertainties.

Uncertainty in pre-industrial natural emission estimates also arises from the lack of complete understanding about the influence of anthropogenic changes prior to the industrial revolution (such as the expansion of agriculture) and from temporal variability of natural emissions. Between 1730 and $1850, \mathrm{~N}_{2} \mathrm{O}$ concentrations in the atmosphere varied slightly from year to year and decade to decade, but showed little or no consistent long term trend (Machida et al 1995). Although Syakila and Kroeze (2011) estimated that average net anthropogenic emissions were around $0.5 \mathrm{Tg} \mathrm{N}_{2} \mathrm{O}-\mathrm{N} \mathrm{yr}^{-1}$ during the 18th and early 19th centuries, these possible anthropogenic emissions were sufficiently low that their signal cannot be distinguished from the effects of climatic variation on natural emissions.

Despite the uncertainties, both bottom-up and top-down approaches suggest that natural emissions were and probably still are between 10 and $12 \mathrm{Tg} \mathrm{N}_{2} \mathrm{O}-\mathrm{N} \mathrm{yr}^{-1}$. We will concentrate the rest of our analyses on anthropogenic effects since 1850

\section{Anthropogenic emissions}

\subsection{Top-down atmospheric modeling constraints}

Modern anthropogenic emissions of $\mathrm{N}_{2} \mathrm{O}$ can be calculated using the same top-down method described above (equation (1)). In this case, the changes in atmospheric concentrations from 1850 to the present (Machida et al 1995,
NOAA 2014) are assumed to be entirely anthropogenic, assuming relative stability of natural emissions over the same period and the same atmospheric $\mathrm{N}_{2} \mathrm{O}$ lifetime of $120( \pm 10)$ years. The natural emission estimate $\left(11 \mathrm{Tg} \mathrm{N} \mathrm{yr}^{-1}\right)$ is subtracted from the total modern emissions calculated from equation (1) to yield modern net anthropogenic emissions. We averaged the emission estimates for the period 2000-2007 to avoid artifacts of short-term interannual variation, yielding an estimate for net anthropogenic emissions of $5.3 \mathrm{Tg} \mathrm{N}_{2} \mathrm{O}$ $\mathrm{N} \mathrm{yr}^{-1}$ (range 5.2-5.5) for that period. This estimate includes all anthropogenic activities that have contributed to changing atmospheric $\mathrm{N}_{2} \mathrm{O}$, including any decrease in emissions from forest soils because of deforestation and increases in emissions from expanded activity in agriculture and other sectors.

\subsection{Bottom-up inventory estimates}

Protocols have been developed by the IPCC (2006) for countries to estimate their $\mathrm{N}_{2} \mathrm{O}$ emissions. The IPCC Tier 1 Protocol multiplies metrics of activity in agriculture, energy generation, transportation, and other sectors, by emission factors (EFs), the amount of $\mathrm{N}_{2} \mathrm{O}$ emitted per unit of activity. For example, the direct emissions of $\mathrm{N}_{2} \mathrm{O}$ from agricultural soils are estimated as a $1 \% \mathrm{EF}$ applied to synthetic-N fertilization application activity rates. Additional EFs are used to calculate the amount of fertilizer $\mathrm{N}$ leached into surface and groundwaters and volatilized as ammonia or nitrogen oxide gases, and the subsequent indirect $\mathrm{N}_{2} \mathrm{O}$ emissions from downstream and downwind ecosystems, which often are substantial. For example, emissions from coastal, estuarine and riverine waters are estimated to be about $9 \%$ of total anthropogenic sources (Ciais et al 2013), although the original source of most of this $\mathrm{N}$ was from agricultural field applications. The EFs have been derived from the literature and are periodically revised as warranted. By necessity, they are averages across a broad range of conditions and often do not yield accurate estimates for individual sites. Nevertheless, there is evidence that errors on the small scale are largely canceled when aggregated to larger scales (Del Grosso et al 2008).

Another source of inaccuracy in the use of Tier 1 EFs is that they assume a linear relationship between $\mathrm{N}$ application rates and $\mathrm{N}_{2} \mathrm{O}$ emissions. A growing number of studies demonstrate nonlinear (usually exponential) relationships between $\mathrm{N}$ application rate and $\mathrm{N}_{2} \mathrm{O}$ emissions (Shcherbak et al 2014). The nonlinear relationship is likely the result of large increases in $\mathrm{N}_{2} \mathrm{O}$ emissions once $\mathrm{N}$ application rates are in excess of plant demands. This has important implications for targeting mitigation where $\mathrm{N}$ application rates are higher than $\mathrm{N}$ harvested in crop export and for not discouraging additional $\mathrm{N}$ application in $\mathrm{N}$-deficient regions where mining of soil nutrients is common, such as sub-Saharan Africa. The implications of nonlinearity are not yet clear for global $\mathrm{N}_{2} \mathrm{O}$ budgets. The differences between linear and nonlinear models for estimating $\mathrm{N}_{2} \mathrm{O}$ emissions are more likely to be important at the farm scale compared to the global scale, because the biases of the linear model (probably overestimation of fluxes where $\mathrm{N}$ applications are low and underestimation where $\mathrm{N}$ 
application rates are high) at least partially cancel as the spatial scale increases.

The United Nations Food and Agriculture Organization (FAO) estimates agricultural $\mathrm{N}_{2} \mathrm{O}$ emissions by applying IPCC Tier 1 EFs to their country data gathered from national publications and questionnaires. The Emissions Database for Global Atmospheric Research (EDGAR) database uses a blend of private and public data, applying IPCC Tier 1 EFs to estimate both non-agricultural and agricultural $\mathrm{N}_{2} \mathrm{O}$ emissions (with the exception of biomass burning, where they apply EFs described in Andreae and Merlet (2001).

A variant of the bottom-up global inventory approach involves a combination of 'top-down' constraints, based on a global atmospheric budget, and 'bottom-up' inventory estimates of minor $\mathrm{N}_{2} \mathrm{O}$ sources from biomass burning, industry, energy, and transportation sectors, and from statistical correlations at the global scale using data on fertilizer use, manure production, and land-use change (Crutzen et al 2008, Davidson 2009, Smith et al 2012). These approaches yield EFs based on newly fixed N (either Haber-Bosch or biological $\mathrm{N}$ fixation) and $\mathrm{N}$ remobilized from tillage of soils (Smith et al 2012) or through production of manure by livestock (Davidson 2009). They implicitly include both direct and indirect emissions (i.e., on the farm and downwind and downstream) from these $\mathrm{N}$ fluxes, so comparison with the IPCC EFs is not straightforward. Nevertheless, the estimates from Davidson (2009) of $2.0 \%$ of manure-N and $2.5 \%$ of fertilizer- $\mathrm{N}$ converted to $\mathrm{N}_{2} \mathrm{O}$ are not far off of the sums of IPCC EFs for direct and indirect agricultural emissions and human sewage. The estimate from Smith et al (2012) that 4\% of newly fixed $\mathrm{N}$ is converted to $\mathrm{N}_{2} \mathrm{O}$ may not be far off of the sum of IPCC EFs when the cascading effects of newly fixed $\mathrm{N}$ moving through croplands, livestock operations, downwind and downstream ecosystems, and human sewage are considered.

Countries that have sufficient data to calculate EFs more specific to their particular situations are allowed to use them under IPCC's Tier 2 Protocol, which presumably yields more accurate estimates for those specific regions and management practices (IPCC 2006). Under the Tier 3 Protocol, countries with access to validated biogeochemical models and sufficient input data are allowed to use these models to calculate $\mathrm{N}_{2} \mathrm{O}$ emissions (IPCC 2006). This presumably yields even more accurate estimates if the models skillfully account for spatial and temporal variation of the most important factors affecting emissions.

With the advent of new laser technologies for measurements of $\mathrm{N}_{2} \mathrm{O}$ fluxes (e.g., Savage et al 2014) there is likely to be continued improvement in estimating emission factors for the Tier 1 and Tier 2 Protocols and for developing and validating the biogeochemical models used with the Tier 3 Protocol. However, it will remain difficult to fully account for the large spatial and temporal variation of $\mathrm{N}_{2} \mathrm{O}$ emissions. Improvement in the quality of activity data for each country, such as its fertilizer application rates, livestock production, and manure handling procedures, is also necessary for improved emission estimates. New EFs are also needed for new cropping systems, such as second generation biofuel crops. Indeed, fertilizer application rates and EFs for biofuel production are among the largest uncertainties for projections of future $\mathrm{N}_{2} \mathrm{O}$ emissions (see section 5.2).

Table 1 summarizes recent efforts at partitioning anthropogenic emissions from bottom-up inventories and from integrated bottom-up and top-down analyses. Here we adopt the recent estimates from UNEP (2013) for total net anthropogenic $\mathrm{N}_{2} \mathrm{O}$ emissions of $5.3 \mathrm{Tg} \mathrm{N}_{2} \mathrm{O}-\mathrm{N} \mathrm{yr}^{-1}$, which is equal to the top-down estimate (section 3.1). The 'best estimate' from the UNEP report is lower than the estimates from other inventories shown in table 1, partly because of some lower updated sectoral estimates and partly due to including the effect of lower tropical forest soil emissions resulting from historic and on-going deforestation, which is neglected in many other inventories. The best estimate of gross anthropogenic emissions is $6.2 \mathrm{Tg} \mathrm{N}_{2} \mathrm{O}-\mathrm{N} \mathrm{yr}^{-1}$. Because tropical forest soils are a large natural source of $\mathrm{N}_{2} \mathrm{O}$ emissions, tropical deforestation should be considered as a significant human-induced decrease in emissions. Soil $\mathrm{N}_{2} \mathrm{O}$ emissions from recently converted tropical forests may initially increase, but the long-term trend is for emissions from the pasture soils and degraded land soils to be lower than those from intact, mature tropical forests (Davidson et al 2001, Melillo et al 2001), resulting in current estimates of a decreased source of $0.9 \mathrm{Tg} \mathrm{N}_{2} \mathrm{O}-\mathrm{N} \mathrm{yr}^{-1}$ (Davidson 2009). Subtracting the effect of tropical deforestation from the estimate of gross anthropogenic emissions yields a best estimate of $5.3 \mathrm{Tg}$ $\mathrm{N}_{2} \mathrm{O}-\mathrm{N} \mathrm{yr}^{-1}$ for net anthropogenic emissions, which is $15 \%$ below the gross anthropogenic emission estimate. Without this adjustment, the bottom-up and top-down approaches would not agree, although the apparent exact agreement to a tenth of a teragram is probably partly fortuitous.

\subsection{Anthropogenic emissions by sector}

Significant uncertainties remain for activity data and especially for several of the emission factors in each sector. Brief summaries of expert analyses from each sector from chapters 4-7 of the UNEP (2013) report are presented here.

3.3.1. Agriculture. Agriculture is the largest source of anthropogenic $\mathrm{N}_{2} \mathrm{O}$ emissions, responsible for $4.1 \mathrm{Tg} \mathrm{N}_{2} \mathrm{O}$ $\mathrm{N} \mathrm{yr}^{-1}$ (3.8-6.8 $\mathrm{Tg} \mathrm{N}_{2} \mathrm{O}-\mathrm{N} \mathrm{yr}^{-1}$; Oenema et al 2013) or $66 \%$ of total gross anthropogenic emissions (table 1). Emission estimates include direct soil emissions from synthetic $\mathrm{N}$ fertilizer and manure application and indirect emissions that occur from downstream or downwind water bodies and soils after nitrate leaches away from croplands and after $\mathrm{N}$ emitted from croplands as ammonia or nitrogen oxide gases fall back to earth as atmospheric $\mathrm{N}$ deposition. Also included are $\mathrm{N}_{2} \mathrm{O}$ emissions resulting from crop residues, manure management, cultivation of organic soils, and crop biological $\mathrm{N}$ fixation (CBNF). The central factor responsible for agricultural $\mathrm{N}_{2} \mathrm{O}$ emissions is a lack of synchronization between crop $\mathrm{N}$ demand and soil $\mathrm{N}$ supply, with, on average, around $50 \%$ of $\mathrm{N}$ applied to soils not being taken up by the crop (Snyder et al 2009, Oenema et al 2013, Venterea et al 2012). Inputs of $\mathrm{N}$ to agricultural soils are mainly from synthetic $\mathrm{N}$ fertilizer 
and manure application, with additional supply from legume $\mathrm{N}$ fixation, crop residues, and $\mathrm{N}$ deposition.

3.3.2. Industry and fossil fuel combustion. The industry sector plus fossil fuel combustion (stationary combustion and transportation) together are responsible for about $0.9 \mathrm{Tg} \mathrm{N}_{2} \mathrm{O}$ $\mathrm{N} \mathrm{yr}^{-1}\left(0.7-1.6 \mathrm{Tg} \mathrm{N}_{2} \mathrm{O}-\mathrm{N} \mathrm{yr}^{-1}\right)$ or $15 \%$ of total gross anthropogenic $\mathrm{N}_{2} \mathrm{O}$ emissions (Wiesen et al 2013). Nitric and adipic acid production are the major industrial sources. Nitric acid is mainly used as a feedstock in the production of explosives and $\mathrm{N}$ fertilizer, particularly ammonium nitrate, with $\mathrm{N}_{2} \mathrm{O}$ emitted during the ammonia oxidation process (Lee et al 2011). Adipic acid is a key feedstock in synthetic fiber production, with $\mathrm{N}_{2} \mathrm{O}$ resulting from the use of nitric acid to oxidize several organic chemicals (Schneider et al 2010). Stationary combustion (mainly coal power plants) is the principal source of $\mathrm{N}_{2} \mathrm{O}$ from the energy sector. Emissions of $\mathrm{N}_{2} \mathrm{O}$ from this sector arise via the oxidation of both atmospheric $\mathrm{N}_{2}$ and organic $\mathrm{N}$ in fossil fuels. Emissions vary with the amount of organic $\mathrm{N}$ in the fuel, the operating temperature, and the oxygen levels during combustion (EPA 2012). $\mathrm{N}_{2} \mathrm{O}$ from transport is released primarily by catalytic converters used to control $\mathrm{NO}_{\mathrm{x}}$, carbon monoxide, and hydrocarbons in tailpipe emissions, with older technologies responsible for significantly higher emission rates per kilometer than more advanced technologies (IPCC 2006).

3.3.3. Biomass burning. Biomass burning is currently responsible for about $0.7 \mathrm{Tg} \mathrm{N}_{2} \mathrm{O}-\mathrm{N} \mathrm{yr}^{-1}\left(0.5-1.7 \mathrm{Tg} \mathrm{N} \mathrm{N}_{2} \mathrm{O}-\right.$ $\mathrm{N} \mathrm{yr}^{-1}$; van der Werf et al 2013) or $11 \%$ of total gross anthropogenic emissions. This includes crop residue burning, forest fires (resulting from both natural and human activities), and prescribed savannah, pasture, and cropland burning. It also includes $\mathrm{N}_{2} \mathrm{O}$ emissions from household biomass stoves. $\mathrm{N}_{2} \mathrm{O}$ is released via the oxidation of organic $\mathrm{N}$ in biomass during combustion. Although some wildfires are ignited naturally by lightning, all emissions from biomass burning have been attributed as anthropogenic emissions, because it is impossible to separate out which wildfires are ignited by humans. Furthermore, anthropogenic climate change may also be increasing fire frequency and severity (Pechony and Shindell 2010).

3.3.4. Wastewater, aquaculture, and other sources. $\mathrm{N}_{2} \mathrm{O}$ emissions from wastewater were $0.2 \mathrm{Tg} \mathrm{N}_{2} \mathrm{O}-\mathrm{N} \mathrm{yr}^{-1}$ in 2010 (Bouwman et al 2013), or $3 \%$ of total gross anthropogenic emissions. This includes $\mathrm{N}_{2} \mathrm{O}$ emitted either directly from wastewater effluent or from bioreactors removing $\mathrm{N}$ in biological nutrient removal plants (Law et al 2012). A small amount of $\mathrm{N}_{2} \mathrm{O}$ is also emitted in aquaculture $(<0.1 \mathrm{Tg}$ $\mathrm{N}_{2} \mathrm{O}-\mathrm{N} \mathrm{yr}^{-1}$ in 2010). Various human-related changes to the oceanic environment have affected the amount of $\mathrm{N}_{2} \mathrm{O}$ emissions produced by the oceans. Increased $\mathrm{N}$ deposition onto the ocean has been estimated to have increased the oceanic $\mathrm{N}_{2} \mathrm{O}$ source by $0.2 \mathrm{Tg} \mathrm{N}_{2} \mathrm{O}-\mathrm{N} \mathrm{yr}^{-1}(0.08-0.34 \mathrm{Tg}$ $\mathrm{N}_{2} \mathrm{O}-\mathrm{N} \mathrm{yr}^{-1}$ ) or $3 \%$ of total gross anthropogenic emissions
(Suntharalingam et al 2012). In principle, increased oceanic emission due to $\mathrm{N}$ deposition should be included in the indirect emission estimates from agricultural, energy, and transportation sources, but it is included here as a separate category because the oceans may have been underrepresented in calculations of emissions from downwind and downstream ecosystems.

\section{Trends in emissions over the last 20 years}

Figure 2 illustrates how $\mathrm{N}_{2} \mathrm{O}$ emissions from three of the most important sectors of the EDGAR (2009) database have changed from 1990 to 2008 . The dominance of emissions by agricultural soils is clear, with the importance of South Asia, parts of Latin America and especially East Asia growing in the last two decades. Large-scale biomass burning emissions are most important in tropical savannah regions. Industrial emissions are most important in developed countries and are growing in South and East Asia.

\section{Emission projections}

\subsection{Synthesis of published scenarios}

Projections of future emissions depend upon assumptions about changes in:

- Population growth rates.

- Per capita consumption of calories and protein.

- Relative sources of vegetable versus animal products for meeting food demands.

- Rates of wastage/loss of food from production to consumption.

- Nutrient use efficiency in crop and animal production systems.

- Production of newly fixed $\mathrm{N}$ for agriculture (including biofuels) and aquaculture.

- Emissions of $\mathrm{NH}_{3}$ and $\mathrm{NO}_{\mathrm{x}}$ from all sectors, which contribute to $\mathrm{N}$ deposition on native soils and oceans.

- Fire frequency, including household biomass burning, slash-and-burn agriculture, pasture clearing, and wildfire.

- Industrial and energy sectors (such as fertilizer manufacturers and industries using coal combustion) that can reduce emissions.

- Land-use change.

- Energy sector technology and demand for biofuels.

- Climate and its effects on $\mathrm{N}$ cycling processes.

Climate change can affect $\mathrm{N}_{2} \mathrm{O}$ emissions from water bodies and soils under native vegetation, but this effect is not well represented in current models (Pinder et al 2012) and it is not dealt with here. Most published projections of future emissions focus on assumptions about changes in emissions from agriculture, biomass burning, energy, transportation, and industry, which vary widely among the scenarios considered here (table 2) and elsewhere (e.g. Bodirsky et al 2014). Here, four sets of published $\mathrm{N}_{2} \mathrm{O}$ emission scenarios were 


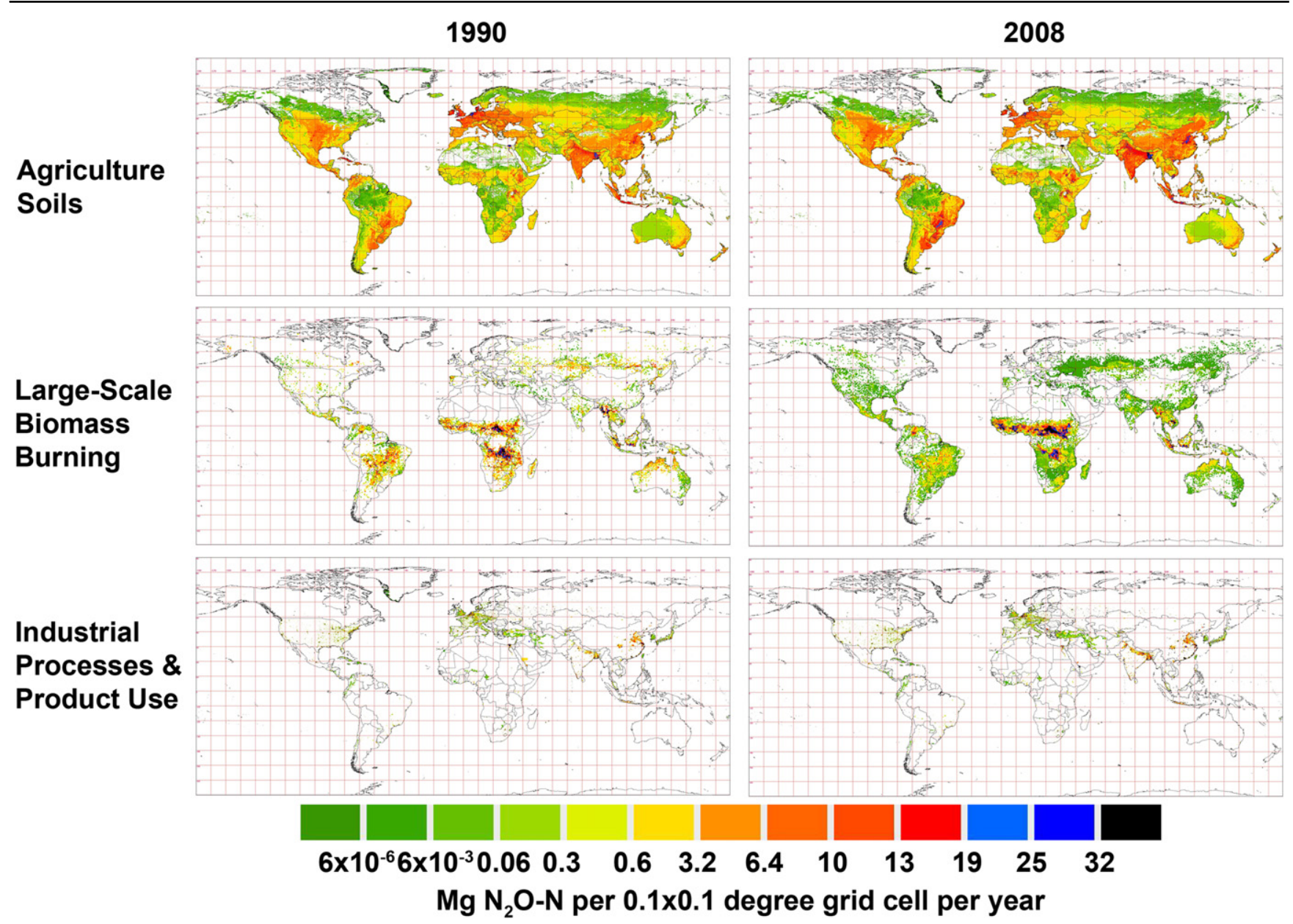

Figure 2. Global maps of direct emissions from agricultural soils, large scale biomass burning, and industrial process (mostly adipic and nitric acid production) for 1990 and 2008 from the Emissions Database for Global Atmospheric Research (EDGAR), version 4.0 (2009) (http:// edgar.jrc.ec.europa.eu). Units are tons of $\mathrm{N}_{2} \mathrm{O}-\mathrm{N}$ per $0.1 \times 0.1$ degree grid cell per year. Note that this size grid cell is about $123 \mathrm{~km}^{2}$ at the equator and declines with increasing latitude, approaching zero near the poles. Reprinted, with permission, from Davidson et al (2013), (figure 3.2).

aggregated to characterize the potential range of future anthropogenic emissions:

- The Special Report on Emissions Scenarios (SRES) (Nakicenovic et al 2000) created four major global greenhouse gas emissions scenarios (A1, A2, B1 and B2) based on the degree of globalization versus regionalization and the priority given to economic versus social and environmental objectives. These were used in the IPCC's Third and Fourth Assessment Reports.

- The RCPs (Van Vuuren et al 2011a) are used in the IPCC $\mathrm{AR} 5$, with four scenarios based on differing radiative forcing levels rather than emissions (RCP 2.6, 4.5, 6.0 and 8.5 , with the numbers referring to different radiative forcing levels in $\mathrm{Wm}^{-2}$ in the year 2100).

- Davidson (2012) used FAO projections of population and dietary demands to estimate fertilizer and manure demands and subsequent $\mathrm{N}_{2} \mathrm{O}$ emissions, including five variants (S1-S5) of mitigation and dietary habits.

- Five scenarios of a new UNEP report (Sutton et al 2013) based on expert analyses of feasible mitigation options in each sector: TR1: Business-As-Usual; TR2: Mitigation of Industry, Fossil Fuel Combustion, and Biomass Burning; TR3: Efficiency of Agricultural Production; TR4: Efficiency of Agricultural Production and Consumption; and TR5: Combined Mitigations.

These studies have different base years and employ different inventory sources. In order to make their results comparable, all emission estimates were normalized to the best estimate of 2005-2010 average net anthropogenic emissions from the UNEP report $\left(5.3 \mathrm{Tg} \mathrm{N}_{2} \mathrm{O}-\mathrm{N} \mathrm{yr}^{-1}\right)$. The scenarios of annual emissions are presented graphically in figure 3 . The numerous scenarios are organized into three groups and means calculated for each group:

\subsection{Business-as-usual scenarios (BAU)}

The RCP 8.5, SRES A2, Davidson's S1, and UNEP1 scenarios have no or little mitigation. On average, the emissions of these scenarios increase to $9.7 \mathrm{Tg} \mathrm{N}_{2} \mathrm{O}-\mathrm{N} \mathrm{yr}^{-1}$ by 2050 , which is nearly double their level in 2005 ( $83 \%$ increase). 
Table 2. Summary of assumptions of published scenarios for future $\mathrm{N}_{2} \mathrm{O}$ emissions.

\begin{tabular}{lll}
\hline Source & Scenario & Description \\
\hline SRES (Nakicenovic et al 2000) & A1 & A world of increased regional, economic, social and cultural convergence drives rapid
\end{tabular}
economic growth and the dissemination of new technologies, with global population peaking at nine billion in 2050 and declining thereafter.

A2 A fragmented world with more regionally focused economic development leads to slower per capita economic growth and technological change than other scenarios. Continuous population growth due to slow convergence of regional fertility patterns.

B1 A global approach to economic, social and environmental sustainability leads to the swift creation of a service and information economy, with a rapid expansion of clean technologies and less resource use. Similar population growth to A1.

B2 A similar commitment to sustainability as in B1, but with an emphasis on local solutions. Continuous population growth (at a slower rate than A2), moderate levels of economic development, with slower and more varied technological change than A1 and B1.

RCPs (van Vuuren et al 2011a) RCP8.5 A high emissions pathway-representing a scenario where little is done to limit climate change-leading to radiative forcing of $8.5 \mathrm{Wm}^{-2}$ in 2100 .

RCP6 An emissions pathway that eventually leads to a stabilization of radiative forcing at $6 \mathrm{Wm}^{-2}$ after 2100 .

RCP4.5 An emissions pathway that eventually leads to a stabilization of radiative forcing at $4.5 \mathrm{Wm}^{-2}$ after 2100 .

RCP2.6 A low emissions pathway-representing ambitious international action to limit climate change - that leads to a peak in radiative forcing at $3 \mathrm{Wm}^{-2}$ before 2100 , dropping to $2.6 \mathrm{Wm}^{-2}$ by 2100 .

Davidson (2012)

Future fertilizer and manure use scaled to FAO projections of population growth, per capita caloric intake and meat consumption.

Developed countries reduce per capita meat consumption to $50 \%$ of 1980 levels by 2030 , remaining constant to 2050 . Results in a $21 \%$ reduction in fertilizer use and manure production by 2030 and 2050 relative to Scenario 1 .

Improved efficiency of fertilizer use and manure production reduces $\mathrm{N}_{2} \mathrm{O}$ emission factors $50 \%$ by 2050 .

S4 The same as Scenario 3, with the addition of emission reductions from industry, energy, transport, and biomass burning of $50 \%$ by 2050 .

S5 A scenario combining the mitigation actions of Scenarios 2 through 4.

UNEP (Sutton et al 2013) TR1 Emissions are projected to increase according to the 'business-as-usual' assumptions presented in Chapters 4 to 7 of UNEP (2013).

TR2 Combined emissions from industry, energy, transport and biomass burning are reduced by $58 \%$ by 2050 relative to Case 1 .

TR3 Improved efficiency of fertilizer use reduces fertilizer demand by $15 \%$ and the $\mathrm{N}_{2} \mathrm{O}$ emission factor for fertilizer $20 \%$ by 2050 relative to Case 1 . Improvements in manure management reduce $\mathrm{N}$ excretion per unit animal product by $30 \%$ and the $\mathrm{N}_{2} \mathrm{O}$ emission factor for manure production $10 \%$ by 2050 relative to Case 1 .

TR4 The efficiency improvements in Case 3 are combined with 50\% reductions in global food waste and developed country meat consumption relative to Case 1 .

TR5 A combination of all the mitigation actions in Cases 2 through 4.

\subsection{Moderate mitigation scenarios}

The scenarios RCP 4.5, RCP 6.0, SRES A1, SRES B1, Davidson's S2 and S3, UNEP2 and UNEP3 have moderate mitigation, defined here as scenarios showing emission trends that are higher than 2005 emissions in 2050 but below BAU. On average, emissions grow to $6.7 \mathrm{Tg} \mathrm{N}_{2} \mathrm{O}-\mathrm{N} \mathrm{yr}^{-1}$ by 2050 , an increase of $26 \%$ relative to 2005 .

\subsection{Concerted mitigation scenarios}

The RCP 2.6, SRES B2, Davidson's S4 and S5, UNEP4, and UNEP5 mitigation scenarios are concerted, because they lead to emissions in 2050 that are below the 2005 level. On average, emissions decline to $4.2 \mathrm{Tg} \mathrm{N}_{2} \mathrm{O}-\mathrm{N} \mathrm{yr}^{-1}$ by 2050 , a decrease of $22 \%$ relative to 2005 .

The concerted mitigation scenarios result in near stabilization of atmospheric concentrations of $\mathrm{N}_{2} \mathrm{O}$ between 340 and 350 ppb by 2050 (Davidson 2012, Davidson et al 2013), whereas $\mathrm{N}_{2} \mathrm{O}$ concentration continues rising beyond 2050 for the $\mathrm{BAU}$ and moderate mitigation scenarios.

By 2020 the average concerted mitigation scenario reduces emissions by $1.8 \mathrm{Tg} \mathrm{N}_{2} \mathrm{O}-\mathrm{N} \mathrm{yr}^{-1}$ or $25 \%$ below the average BAU scenario, equivalent to $0.8 \mathrm{Gt} \mathrm{CO}_{2} \mathrm{eq} \mathrm{yr}^{-1}$ less than BAU (table 3). This is approximately $10 \%$ of the emissions gap that needs to be bridged by 2020 for it to be 'likely' that average global warming stays below a $2{ }^{\circ} \mathrm{C}$ 


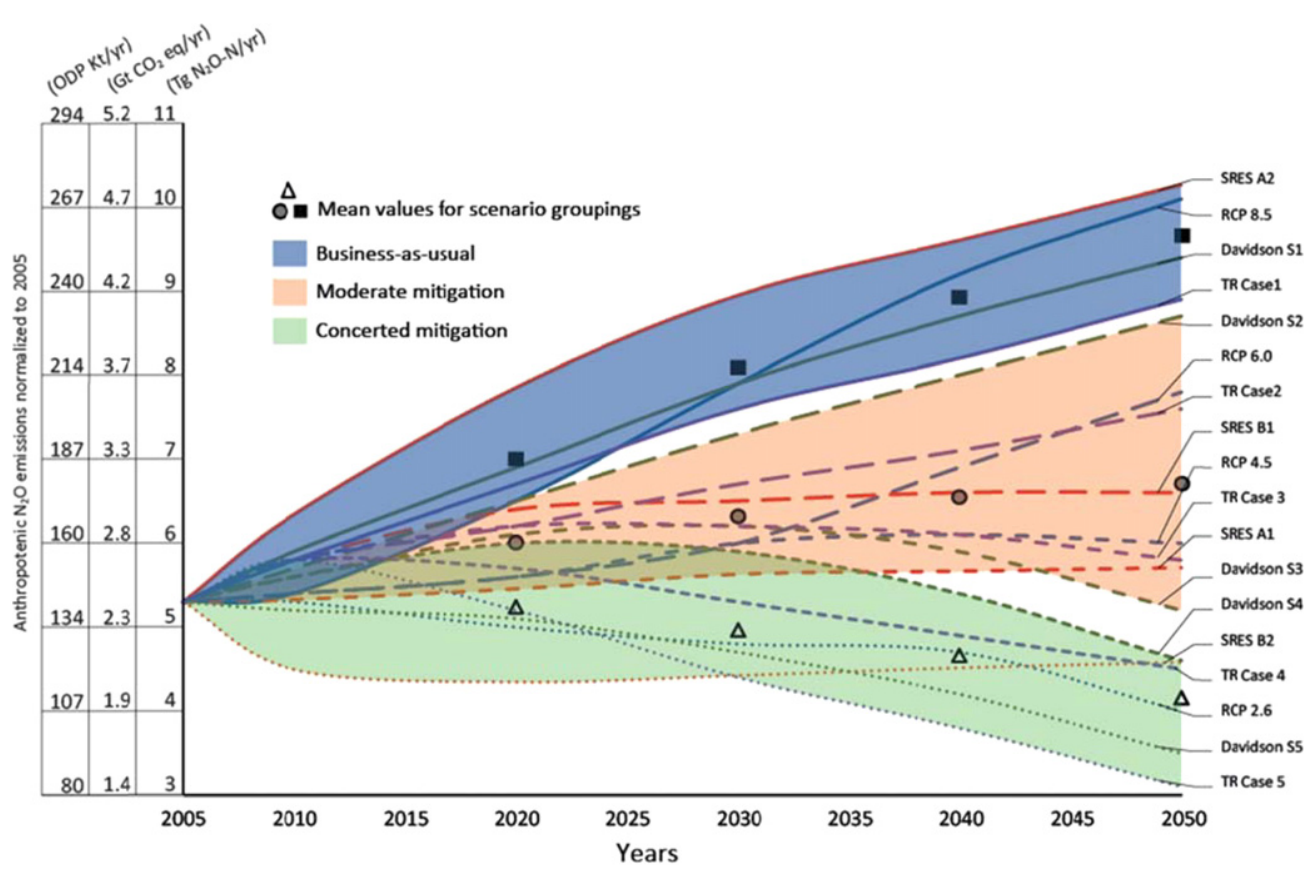

Figure 3. Projections of anthropogenic $\mathrm{N}_{2} \mathrm{O}$ emissions according to groupings of published business-as-usual, moderate mitigation, and concerted mitigation scenarios (Nakicenovic et al 2000, Van Vuuren et al 2011a, Davidson 2012, Sutton et al 2013; see table 2). The 'TR' cases 1-5 refer to 'this report', being the 2013 UNEP report (Sutton et al 2013). The mean for each grouping of scenarios is shown by square, circle, and triangle markers. All projections have been adjusted to a common emission estimate baseline in 2005 consistent with the UNEP report's best estimate of net anthropogenic emissions of $5.3 \mathrm{Tg} \mathrm{N}_{2} \mathrm{O}-\mathrm{N} \mathrm{yr}^{-1}$. Concerted scenarios include aggressive mitigation in all sectors and most include reduced per capita meat consumption in the developed world. $Y$-axis units have been converted to $\mathrm{CO}_{2}$ equivalents for a 100-year global warming potential and to Ozone Depletion Potential (ODP; Ravishankara et al 2009). Reprinted, with permission, from Sutton et al (2013), (figure 8.1).

Table 3. Projected annual anthropogenic $\mathrm{N}_{2} \mathrm{O}$ emissions for three emission scenario groupings, given in units of $\mathrm{N}, \mathrm{CO}_{2}$ equivalents, and ozone depletion potential.

\begin{tabular}{|c|c|c|c|c|}
\hline & 2020 & 2030 & 2040 & 2050 \\
\hline \multicolumn{5}{|c|}{ Units: nitrogen equivalents $\left(\mathrm{Tg} \mathrm{N}_{2} \mathrm{O}-\mathrm{N} \mathrm{yr}^{-1}\right)^{\mathrm{a}}$} \\
\hline Business-as-usual & 7.0 & 8.1 & 8.9 & 9.7 \\
\hline & & 6. & 6.5 & 6.7 \\
\hline Concerted mitigation & 5.2 & 5.0 & 4.7 & 4.2 \\
\hline \multicolumn{5}{|c|}{ Units: equivalents of carbon dioxide $\left(\mathrm{Gt} \mathrm{CO}_{2}-\mathrm{eq} \mathrm{yr}^{-1}\right)^{\mathrm{b}}$} \\
\hline Business & 3.3 & 3.8 & 4.2 & 4.5 \\
\hline & 2. & 3. & 3.1 & 3.1 \\
\hline ed mitugaton & 2.5 & 2.3 & 2.2 & 1.9 \\
\hline \multicolumn{5}{|c|}{ Units: ozone depletion potential (ODP kt $\left.\mathrm{yr}^{-1}\right)^{\mathrm{c}}$} \\
\hline usil & 187 & 216 & 238 & 258 \\
\hline & 16 & 16 & 175 & 178 \\
\hline oncerted mitigation & 140 & 133 & 125 & 111 \\
\hline
\end{tabular}

The values are the mean of four sets of scenarios according to SRES (Nakicenovic et al 2000), RCP (van Vuuren et al 2011a), Davidson (2012), and UNEP (2013) and grouped as described in the main text.

Calculated using a 100-year global warming potential of 298 for $\mathrm{N}_{2} \mathrm{O}$.

Calculated using an ozone depleting potential of 0.017 for $\mathrm{N}_{2} \mathrm{O}$. threshold (UNEP 2012). By 2050, the average concerted mitigation scenarios are $57 \%$ lower than the average BAU scenario-around $5.5 \mathrm{Tg} \mathrm{N}_{2} \mathrm{O}-\mathrm{N} \mathrm{yr}^{-1}$ (2.6 Gt $\left.\mathrm{CO}_{2} \mathrm{eq} \mathrm{yr}^{-1}\right)$. The avoided emissions between 2014 and 2050 sum to $22 \mathrm{Tg}$ $\mathrm{N}_{2} \mathrm{O}-\mathrm{N}$ (57 Gt $\mathrm{CO}_{2} \mathrm{eq}$ ). To put this figure in context, it is equal to about ten years of the $\mathrm{CO}_{2}$ emissions of all of the passenger cars currently on the road.

The impact of $\mathrm{N}_{2} \mathrm{O}$ on stratospheric ozone depletion has been estimated using an ozone-depletion potential (Ravishankara et al 2009; ODP - a measure of its ozone destructiveness relative to CFC-11, which is defined as an ODP of 1). Although the use of ODPs is controversial because of complex interactions of various anthropogenic gases and stratospheric temperature (Fleming et al 2011), we employ it here to place the potential impact of $\mathrm{N}_{2} \mathrm{O}$ mitigation on stratospheric ozone in context with previous efforts to mitigate CFCs. By 2050, the difference between the concerted average mitigation scenario and the average BAU scenario (147 ODP

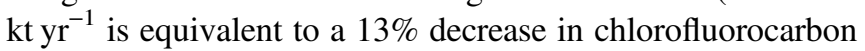
(CFC) emissions from their peak in the late 1980s, approximately halving ODP-weighted emissions in 2050 compared to BAU (table 3 ). The sum of the avoided emissions between 2014 and 2050 is 3270 ODP kt. These reductions would be $40 \%-110 \%$ greater than the potential reductions from the destruction of the remaining recoverable stocks of other ozone depleting substances, which has been identified as the most substantive remaining action that could be taken to accelerate ozone layer recovery (UNEP 2010). 
An important caveat of these projections is that they all begin in 2005, and significant differences are already apparent in their trajectories by 2013. So far (up to 2013), actual global $\mathrm{N}_{2} \mathrm{O}$ emissions have been closer to BAU trajectories than the mitigation trajectories.

\subsection{Projecting $\mathrm{N}_{2} \mathrm{O}$ emissions from biofuel production}

Another caveat of these projections is that the highly uncertain impact of expansion of biofuel production is not considered (Davidson et al 2013). In addition to uncertainties about total biofuels produced, the $\mathrm{N}$ fertilization rates needed for producing second- or third-generation fuel stocks and the $\mathrm{N}_{2} \mathrm{O}$ EFs for those cultivation practices are not known. Fertilization rates and EFs for rapidly growing trees and native grasses, forbs, and shrubs may be much lower than for most current food and fiber crops. To put this uncertainty into perspective, two methods are offered here to bound the range of future $\mathrm{N}_{2} \mathrm{O}$ emissions from biofuels-one based on the potential for energy production and the other based on total land available for biofuel crops.

For the first method, Edenhofer et al (2011) estimate a bioenergy deployment range of $100-300 \mathrm{EJ} \mathrm{yr}^{-1}$ by 2050 , which takes into account soil conservation and biodiversity goals, as well as potential water scarcity and the use of land for subsistence farming (Edenhofer et al 2011, Creutzig et al 2012). For this calculation, it was assumed that by 2050 all bioenergy demand will be supplied by second-generation biofuels. Given data constraints, the estimation focuses on jatropha (Jatropha curcas), miscanthus (Miscanthus $\mathrm{x}$ giganteus), eucalyptus (Eucalyptus cinera) and switchgrass (Panicum virgatum $\mathrm{L}$ ). To estimate emissions, a range of published $\mathrm{N}_{2} \mathrm{O}$ EFs for these biofuels $\left(0.2\right.$ to $27.1 \mathrm{~g} \mathrm{~N}_{2} \mathrm{O}$ $\mathrm{N} \mathrm{kJ}^{-1}$; Hoefnagels et al 2010) was used. This approach generates estimates of $0.02-8.1 \mathrm{Tg} \mathrm{N}_{2} \mathrm{O}-\mathrm{N} \mathrm{yr}^{-1}$ from biofuels by 2050 , depending on the fuel source and the total amount of bioenergy deployed, with a central estimate of $2.1 \mathrm{Tg} \mathrm{N} \mathrm{N}_{2} \mathrm{O}$ $\mathrm{N} \mathrm{yr}^{-1}$ based on the combined means of the bioenergy deployment range and the published emission factors for second-generation biofuels.

The second method focuses on the amount of land potentially available to cultivate biofuel crops. Estimates range from 60-3700 Mha, covering $0.4 \%-28 \%$ of the Earth's land surface, excluding Greenland and Antarctica, with several estimates clustering between 240-500 Mha (Creutzig et al 2012). In comparison, Melillo et al (2009) estimated that 2000 Mha of biofuel crop cultivation will be needed by 2100 to stabilize atmospheric $\mathrm{CO}_{2}$ concentrations at $550 \mathrm{ppm}$, while van Vuuren et al (2011b) estimated that $3000-4000$ Mha will be needed by 2100 in the RCP 2.6 scenario. We assume an average fertilizer application rate of $100 \mathrm{~kg} \mathrm{~N} \mathrm{ha}^{-1} \mathrm{yr}^{-1}$ for land devoted to biofuel crops, as was done by Erisman et al (2008), and use the IPCC (2006) direct and indirect default EFs. Using this approach, $\mathrm{N}_{2} \mathrm{O}$ emissions were estimated to be $0.08-4.9 \mathrm{Tg} \mathrm{N}_{2} \mathrm{O}-\mathrm{N} \mathrm{yr}^{-1}$, depending on the amount of land devoted to biofuel crop cultivation, with a central estimate of $0.5 \mathrm{Tg} \mathrm{N}_{2} \mathrm{O}-\mathrm{N} \mathrm{yr}^{-1}$ based on the mean of the cluster of land-use estimates cited in Creutzig et al (2012).

These estimates are considerably lower than the 16.1-18.6 $\mathrm{Tg} \mathrm{N}_{2} \mathrm{O}-\mathrm{N} \mathrm{yr}^{-1}$ estimated by Melillo et al (2009) for 2100. These data illustrate the huge uncertainty that still remains in future estimates of $\mathrm{N}_{2} \mathrm{O}$ emissions from biofuels. Comparing these estimates from $<1$ to $18 \mathrm{Tg} \mathrm{N}_{2} \mathrm{O}-\mathrm{N} \mathrm{yr}^{-1}$ to the range of the aggregated RCP, SRES and Davidson (2012) scenarios (4.4 to $9.9 \mathrm{Tg} \mathrm{N}_{2} \mathrm{O}-\mathrm{N} \mathrm{yr}^{-1}$, table 3) demonstrates that biofuels could either remain a relatively trivial source or become the most significant source of anthropogenic $\mathrm{N}_{2} \mathrm{O}$ emissions at some point this century. Energy and climate policy decisions in the coming decades as well as the pace of technical innovation will be among the major determinants of future $\mathrm{N}_{2} \mathrm{O}$ emissions from biofuels.

\section{Conclusions}

- Natural $\mathrm{N}_{2} \mathrm{O}$ emissions are most likely between 10 and $12 \mathrm{Tg} \mathrm{N}_{2} \mathrm{O}-\mathrm{N} \mathrm{yr}^{-1}$.

- Both bottom-up and top-down analyses suggest that net anthropogenic $\mathrm{N}_{2} \mathrm{O}$ emissions are now (2005-2010) about 5.3 $\mathrm{Tg} \mathrm{N}_{2} \mathrm{O}-\mathrm{N} \mathrm{yr}^{-1}$.

- Agriculture currently accounts for $56-81 \%$ of gross anthropogenic $\mathrm{N}_{2} \mathrm{O}$ emissions. Some $\mathrm{N}_{2} \mathrm{O}$ emissions associated with food production is inevitable, but future $\mathrm{N}_{2} \mathrm{O}$ emissions from agriculture will be determined by several factors, including population, dietary habits, and agricultural management to improve $\mathrm{N}$ use efficiency.

- The BAU emission scenarios project almost a doubling of anthropogenic $\mathrm{N}_{2} \mathrm{O}$ emissions, from $5.3 \mathrm{Tg} \mathrm{N}_{2} \mathrm{O}$ $\mathrm{N} \mathrm{yr}^{-1}$ in 2005 to $9.7 \mathrm{Tg} \mathrm{N}_{2} \mathrm{O}-\mathrm{N} \mathrm{yr}^{-1}$ in 2050. In contrast, the concerted mitigation scenarios result in an average decline to $4.2 \mathrm{Tg} \mathrm{N} 2 \mathrm{O}-\mathrm{N} \mathrm{yr}^{-1}$ by 2050 , a decrease of $22 \%$ relative to 2005 , which would lead to a near stabilization of atmospheric concentration of $\mathrm{N}_{2} \mathrm{O}$ at about $350 \mathrm{ppb}$.

- The impact of growing demand for biofuels on future $\mathrm{N}_{2} \mathrm{O}$ emissions is highly uncertain, depending on the types of plants grown, their nutrient management, the amount of land dedicated to their cultivation, and the fates of their waste products. $\mathrm{N}_{2} \mathrm{O}$ emissions from second and third generation biofuels could remain trivial or could become the most significant source to date. Research is needed to reduce the uncertainty of the future impact of biofuels on $\mathrm{N}_{2} \mathrm{O}$.

\section{Acknowledgments}

EAD acknowledges support from the NSF Research Coordination Network award DEB-1049744. The authors thank E Suddick and G Fisk for assistance with figure 2 and S Leonard for assistance with figure 3. We also thank other team members of the UNEP report. 


\section{References}

Andreae M O and Merlet P 2001 Emission of trace gases and aerosols from biomass burning Glob. Biogeochem. Cycles 15 955-66

Bodirsky B L et al 2014 Reactive nitrogen requirements to feed the world in 2050 and potential to mitigate nitrogen pollution Nat. Commun. 53858

Bouwman L, van der Sluis S, Zhang G-L, Towprayoon S and Mulsow S 2013 Reducing $\mathrm{N}_{2} \mathrm{O}$ emissions from wastewater and aquaculture Drawing Down N2O to Protect Climate and the Ozone Layer. A UNEP Synthesis Report (Nairobi: United Nations Environment Programme) (www.unep.org/pdf/ UNEPN2Oreport.pdf)

Ciais P et al 2013 Carbon and other biogeochemical cycles Climate Change 2013: The Physical Science Basis. Contribution of Working Group I to the Fifth Assessment Report of the Intergovernmental Panel on Climate Change ed T F Stocker et al (New York: Cambridge University Press)

Creutzig F, Popp A, Plevin R, Luderer G, Minx J and Edenhofer O 2012 Reconciling top-down and bottom-up modelling on future bioenergy deployment Nat. Clim. Change 2 320-7

Crutzen P J, Mosier A R, Smith K A and Winiwarter W $2008 \mathrm{~N}_{2} \mathrm{O}$ release from agro-biofuel production negates global warming reduction by replacing fossil fuels Atmos. Chem. Phys. 8 389-95

Daniel J S, Velders G J M, Solomon S, McFarland M and Montzka S A 2007 Present and future sources and emissions of halocarbons: toward new constraints J. Geophys. Res. 112 D02301

Davidson E A 2009 The contribution of manure and fertilizer nitrogen to atmospheric nitrous oxide since 1860 Nature Geosci. 2 659-62

Davidson E A 2012 Representative concentration pathways and mitigation scenarios for nitrous oxide Environ. Res. Lett. 7 024005

Davidson E A, Bustamante M M C and Pinto A D S 2001 Emissions of nitrous oxide and nitric oxide from soils of native and exotic ecosystems of the Amazon and Cerrado regions of Brazil Optimizing nitrogen management in food and energy production and environmental protection: Proc. of the 2 nd Int. Nitrogen Conf. on Science and Policy ed J Galloway et al (Lisse: A A Balkema Publishers)

Davidson E A, Kanter D, Suddick E and Suntharalingam P 2013 $\mathrm{N}_{2} \mathrm{O}$ : sources, inventories, projections Drawing Down $\mathrm{N}_{2} \mathrm{O}$ to Protect Climate and the Ozone Layer. A UNEP Synthesis Report (Nairobi: United Nations Environment Programme) (www.unep.org/pdf/UNEPN2Oreport.pdf)

Del Grosso S J, Wirth T, Ogle S M and Parton W J 2008 Estimating agricultural nitrous oxide emissions EOS Trans. Am. Geophys. Union 89 529-40

Denman et al 2007 Couplings between changes in the climate system and biogeochemistry Climate change 2007: The Physical Science Basis. Contribution of working Group I to the Fourth Assessment Report of the Intergovernmental Panel on Climate Change ed S Solomon et al (Cambridge: Cambridge University Press)

Edenhofer O, Pichs-Madruga R, Sokona Y and Seyboth K 2011 IPCC Special Report on Renewable Energy Sources and Climate Change Mitigation (New York: Cambridge University Press)

EPA 2012 Global Anthropogenic Non-CO2 Greenhouse Gas Emissions (Washington DC: Environmental Protection Agency) 430-R-12-006

EDGAR 2009 Emissions database for global atmospheric research (EDGAR) version 4.0 (http://edgar.jrc.ec.europa.eu)
Erisman J W, van Grinsven H, Leip A, Mosier A and Bleeker A 2010 Nitrogen and biofuels; an overview of the current state of knowledge Nutr. Cycling Agroecosyst. 86 211-23

Firestone M K and Davidson E A 1989 Microbiological basis of NO and $\mathrm{N}_{2} \mathrm{O}$ production and consumption in soil Exchange of Trace Gases between Terrestrial Ecosystems and the Atmosphere ed M O Andreae and D S Schimel (New York: Wiley)

Fleming E L, Jackman C H, Stolarski R S and Douglass A R 2011 A model study of the impact of source gas changes on the stratosphere for 1850-2100 Atmos. Chem. Phys. 11 8515-41

Forster P et al 2007 Changes in atmospheric constituents and in radiative forcing Climate Change 2007: The Physical Science Basis. Contribution of Working Group I to the Fourth Assessment Report of the Intergovernmental Panel on Climate Change ed S Solomon et al (Cambridge: Cambridge University Press)

Galloway J N et al 2004 Nitrogen cycles: past, present and future Biogeochemistry 70 153-226

Galloway J N, Aber J D, Erisman J W, Seitzinger S P, Howarth R W, Cowling E B and Cosby B J 2003 The nitrogen cascade Bioscience $\mathbf{5 3} 341-56$

Hoefnagels R, Smeets E and Faaij A 2010 Greenhouse gas footprints of different biofuel production systems Renew. Sustainable Energy Rev. 14 1661-94

IPCC 2006 IPCC guidelines for national greenhouse gas inventories (www.ipcc-nggip.iges.or.jp/public/2006gl/)

Law Y, Ye L, Pan Y and Yuan Z 2012 Nitrous oxide emissions from wastewater treatment processes Phil. Trans. R. Soc. B 367 1265-77

Lee S-J, Ryu I-S, Kim B-M and Moon S-H 2011 A review of the current application of $\mathrm{N}_{2} \mathrm{O}$ emission reduction in CDM projects Int. J. Greenh. Gas. Con. 5 167-76

Machida T, Nakazawa T, Fujii Y, Aoki S and Watanabe O 1995 Increase in the atmospheric nitrous-oxide concentration during the last 250 years Geophys. Res. Lett. 22 2921-4

Melillo J M et al 2009 Indirect emissions from biofuels: how important? Science 326 1397-9

Melillo J M, Steudler P A, Feigl B J, Neill C, Garcia D, Piccolo M C, Cerri C C and Tian H 2001 Nitrous oxide emissions from forests and pastures of various ages in the Brazilian Amazon J. Geophys. Res. 106 179-88

Mosier A, Kroeze C, Nevison C, Oenema O, Seitzinger S and Van Cleemput O 1998 Closing the global $\mathrm{N}_{2} \mathrm{O}$ budget: nitrous oxide emissions through the agricultural nitrogen cycle $\mathrm{Nutr}$. Cycling Agroecosyst. 52 225-48

Nakicenovic N et al 2000 Special Report on Emissions Scenarios: A Special Report of Working Group III of the Intergovernmental Panel on Climate Change (New York: Cambridge University Press)

NOAA 2014 Combined nitrous oxide data from the NOAA/ESRL Global Monitoring Division (ftp://ftp.cmdl.noaa.gov/hats/n2o/ combined/HATS_global_N2O.txt)

Oenema $\mathrm{O}$ et al 2013 Reducing $\mathrm{N}_{2} \mathrm{O}$ emissions from agricultural sources Drawing Down $\mathrm{N}_{2} \mathrm{O}$ to Protect Climate and the Ozone Layer. A UNEP Synthesis Report (Nairobi: United Nations Environment Programme) (www.unep.org/pdf/ UNEPN2Oreport.pdf)

Pechony O and Shindell D T 2010 Driving forces of global wildfires over the past millennium and the forthcoming century Proc. Natl. Acad. Sci. 107 19167-70

Pinder R, Davidson E A, Goodale C L, Greaver T L, Herrick J D and Liu L 2012 Climate change impacts of US reactive nitrogen Proc. Natl. Acad. Sci. $1097671-5$

Prather M J, Holmes C D and Hsu J 2012 Reactive greenhouse gas scenarios: systematic exploration of uncertainties and the role of atmospheric chemistry Geophys. Res. Lett. 39 L09803 
Ravishankara A R, Daniel J S and Portmann R W 2009 Nitrous oxide $\left(\mathrm{N}_{2} \mathrm{O}\right)$ : the dominant ozone-depleting substance emitted in the 21 st century Science $326123-5$

Rockström J et al 2009 A safe operating space for humanity Nature 461 472-5

Savage K E, Phillips R and Davidson E A 2014 High temporal frequency measurements of greenhouse gas emissions from soils Biogeosciences 11 2709-20

Schneider L L, Lazarus M and Kollmus A 2010 Industrial $\mathrm{N}_{2} \mathrm{O}$ Projects Under the CDM: Adipic Acid-A Case of Carbon Leakage? (Somerville, MA: Stockholm Environment Institute)

Shcherbak I, Millar N and Robertson G P 2014 A global metaanalysis of the nonlinear response of soil nitrous oxide $\left(\mathrm{N}_{2} \mathrm{O}\right)$ emissions to fertilizer nitrogen Proc. Natl. Acad. Sci. 111 9199-204

Smith K A, Mosier A R, Crutzen P J and Winiwarter W 2012 The role of $\mathrm{N}_{2} \mathrm{O}$ derived from biofuels, and from agriculture in general, in Earth's climate Phil. Trans. R. Soc. B 367 1169-74

Snyder C S, Bruulsema T W and Fixen P E 2009 Review of greenhouse gas emissions from crop production systems and fertilizer management effects Agric. Ecosyst. Environ. 133 247-66

SPARC 2013 SPARC Report on the Lifetimes of Stratospheric Ozone-Depleting Substances, Their Replacements, and Related Species ed M Ko et al SPARC report no. 6, WCRP-15/2013 (Geneva: World Climate Research Programme)

Suntharalingam P, Buitenhuis E, Le Quéré C, Dentener F, Nevison C, Butler J H, Bange H W and Forster G 2012 Quantifying the impact of anthropogenic nitrogen deposition on oceanic nitrous oxide J. Geophys. Res. 39 L07605

Sutton M A, Skiba U M, Davidson E A, Kanter D, van Grinsven H J M, Oenema O, Maas R and Pathak H 2013 Drawing-down $\mathrm{N}_{2} \mathrm{O}$ emissions: scenarios, policies and the green economy Drawing Down $\mathrm{N}_{2} \mathrm{O}$ to Protect Climate and the Ozone Layer. A UNEP Synthesis Report (Nairobi: United Nations Environment Programme) (www.unep.org/pdf/ UNEPN2Oreport.pdf)

Syakila A and Kroeze C 2011 The global nitrous oxide budget revisited Greenhouse Gas Meas. Manage. 1 17-26

UNEP 20102010 Assessment Report of the Technology and Economic Assessment Panel (Nairobi: United Nations Environment Programme)

UNEP 2012 The Emissions Gap Report 2012. A UNEP Synthesis Report (Nairobi: United Nations Environment Programme)

UNEP 2013 Drawing Down $\mathrm{N}_{2} \mathrm{O}$ to Protect Climate and the Ozone Layer. A UNEP Synthesis Report (Nairobi: United Nations Environment Programme) (www.unep.org/pdf/ UNEPN2Oreport.pdf)

van der Werf G R, Meyer C P and Artaxo P 2013 Reducing $\mathrm{N}_{2} \mathrm{O}$ emissions from biomass burning in landscape fires and household stoves Drawing Down $\mathrm{N}_{2} \mathrm{O}$ to Protect Climate and the Ozone Layer. A UNEP Synthesis Report (Nairobi: United Nations Environment Programme) (www.unep.org/pdf/ UNEPN2Oreport.pdf)

Van Vuuren D P et al 2011a The representative concentration pathways: an overview Clim. Change 109 5-31

Van Vuuren D P et al 2011b RCP2.6: exploring the possibility to keep global mean temperature increase below $2 \mathrm{C}$ Clim. Change 109 95-116

Venterea R T et al 2012 Challenges and opportunities for mitigating nitrous oxide emissions from fertilized cropping systems Front. Ecol. Environ. 10 562-70

Wiesen P, Wallington T J and Winiwarter W 2013 Reducing $\mathrm{N}_{2} \mathrm{O}$ emissions from industry and fossil fuel combustion Drawing Down $\mathrm{N}_{2} \mathrm{O}$ to Protect Climate and the Ozone Layer. A UNEP Synthesis Report (Nairobi: United Nations Environment Programme) (www.unep.org/pdf/UNEPN2Oreport.pdf) 